\title{
Anatomía de los hombres grises: Rescrituras de la novela social en el Chile de postdictadura*
}

\author{
Anatomy of failure: Newritings of chilean social novel \\ in postdictatorship era
}

Cristián Opazo

Pontificia Universidad Católica de Chile. Chile

cmopazo@uc.cl

\section{RESUMEN}

Estudio narratológico cuya hipótesis señala que en el Chile de la post-dictadura emerge una serie de textos que recuperan los imaginarios urbanos de la novela social, escrita bajo la efervescencia de los gobiernos frente-populistas. En estas novelas del "cambio de milenio", el sujeto de la enunciación es lo que aquí se denomina hombre gris: Subjetividad conservadora que pretende conjurar los "maleficios" de la globalización merced a la invocación (relectura) de los textos de la novela social (e.g. N. Guzmán).

Palabras claves: Novela chilena siglo XX, imaginarios urbanos, post-dictadura.

\section{ABSTRACT}

The statement of this essay emphasizes that in Chilean post-dictatorship era, emerge a kind of narrative-writing that evoke the ideological project of novela social: chilean socialist realism in literature (1930-1940). In this narrative works, the subject of enunciation is named hombre gris, the man of disappointment. The main objective of this aesthetic project is to reject globalization and recovery literary language and ideology of socialist novelists (e.g. N. Guzmán, among others).

Keywords: Chilean novel XXTh century, urban imaginaries, chilean post-dictatorship era.

Recibido: 09-03-2009. Aceptado: 31-03-2009.

*Este trabajo forma parte del Proyecto FONDECYT 1051005: Memorias del 2000: Narrativa chilena y globalización. 
Zn su Cuenta a la nación del 21 de mayo de 1939, el Presidente de la ERepública de Chile, Pedro Aguirre Cerda, sentenció:

Para que la enseñanza pueda cumplir su misión social con toda amplitud es necesario que sea: gratuita, única, obligatoria y laica. Gratuita, a fin de que todos los niños puedan beneficiarse de la cultura, sin otras restricciones que las que se deriven de su propia naturaleza; única, en el sentido de que todas las clases chilenas unifiquen su pensamiento y su acción dentro de las mismas aulas escolares; obligatoria, pues es deber del Estado dar a todos los miembros de la sociedad el mínimo de preparación requerido por la comunidad para la vida cívica y social; laica, con el fin de garantizar la libertad de conciencia y hacer que nada perturbe el espíritu del niño (Aguirre Cerda, 1939: 70).

Para los sectores "progresistas" de la política chilena, el gobierno frentepopulista de Aguirre Cerda (1938-1941) constituye su mito democrático dilecto. Las reformas sociales introducidas por sus caudillos son consideradas, al día de hoy, ejemplos de gestión eficiente, moderna y proba ${ }^{1}$. Esta mirada halagüeña que nuestros intelectuales y políticos posan sobre el pasado tiene su correlato en la producción literaria de las nuevas generaciones de narradores afines al ideario de la izquierda parlamentaria ${ }^{2}$. Efectivamente, quien revise la novelística de postdictadura, se encontrará con un conjunto de textos escritos entre 1990 y $2005^{3}$, cuya prosa exhibe la subjetividad de una clase media que aún llora la caída de sus "utopías vindicativas" -fraguadas, otrora, al alero de

${ }^{1}$ Bernardo Subercaseaux (2008) explica que "el Frente Popular y sus sucesivos gobiernos (...) contribuyeron (...) a una izquierdización del espectro político e incluso del Estado. En efecto, del Estado provino la ayuda oficial al viaje de Winnipeg, viejo barco de carga que en agosto de 1939 zarpó de un puerto francés a Valparaíso, trayendo aproximadamente 2.200 refugiados españoles, entre los que venían cientos de intelectuales, profesionales y artistas" (223). Esta preocupación por la cultura trascendió los intereses de los intelectuales, pues, se vio complementada por la implementación de programas orientados al mejoramiento de los hábitos culturales de las capas bajas y medias. Ejemplo de esto fue el programa de Defensa de la raza y el aprovechamiento de las horas libres, cuyo propósito fue la instrucción en el arte de grupos proletarios y subproletarios merced a la construcción de hogares de esparcimiento.

${ }^{2}$ Nuevas generaciones es el nombre que Rodrigo Cánovas (1997) da a los escritores chilenos nacidos entre 1950 y 1964 (aprox.). Estos escritores conforman una generación emergente, puesto que ya han escrito novelas de calidad no despreciable, son leídos por la crítica y el público, tienen figuración en los medios de comunicación y cuentan con aceptable respaldo de editoriales transnacionales. El leit motiv de estos escritos es el sentimiento de orfandad que suscita en sus narradores la emergencia política de 1973 (Cánovas, 1997: 9-15, 39-47). La generación que Cánovas llama nueva, corresponde a aquella que Cedomil Goic (1972) -desde una perspectiva positivista- denomina generación infrarrealista de 1987 (74). El texto de Cánovas es menos que una impugnación parricida del modelo de Goic que una reelaboración desde la experiencia afectiva.

${ }^{3}$ Las novelas y autores a los que me estoy refiriendo, entre otras, son: Mercenario ad-honorem (1991), de Gregory Cohen (1953); La secreta guerra santa de Santiago de Chile (1989), de Marco 
los gobiernos frente-populistas ${ }^{4}$. Leer las novelas de Cohen, De la Parra, Díaz Eterovic, Oses o Sportorno, es, a fin de cuentas, asomarse a las autopistas del presente sentado en los tranvías de antaño. $\mathrm{O}$, lo que es equivalente, deambular por la aldea global con la impostura de un académico que añora los tiempos en que la Universidad de Chile marcaba el pulso de la vida nacional (Machos tristes, de Oses), de un procurador condenado a archivar expedientes en el sótano de los Tribunales de Justicia (Poderes fácticos, de Tromben), de un detective obligado a esclarecer casos de adulterio matrimonial (El color de la piel, de Díaz Eterovic) y, en el mejor de los casos, de un periodista con pretensiones literarias forzado a escribir eslóganes publicitarios (Mercenario ad-honorem, de Cohen).

Diagnóstico -y esta es la tesis de este ensayo- que en el fin de siglo estamos ante un nuevo sujeto de la enunciación, el hombre gris: figura (narrador o personaje) que en cada uno de los relatos citados resiste los cambios del presente (e.g. globalización, transición a la democracia) a través de la evocación melancólica de la vida cívica de esa ciudad que gobernaron los caudillos frentepopulistas y que inmortalizaron los novelistas sociales.

Antonio de la Parra (1952); El color de la piel (2003), de Ramón Díaz Eterovic (1956); Machos tristes (1991), de Darío Oses (1949); La patrulla de Stalingrado (1994), de Radomiro Spotorno (1950) y Poderes fácticos (2003), de Carlos Tromben (1966).

${ }^{4}$ Aquí, siguiendo a Ángel Rama (1984), aludo a los regímenes populistas latinoamericanos que, proclamando la díada "educación popular + nacionalismo," intentaron, con distinta suerte, incorporar a la clase media al proceso de modernización continental. En el caso chileno, el sueño del auge de la clase media fue alimentado por los gobiernos del frente-populismo, inaugurados a fines de la década de 1930 con Pedro Aguirre Cerda y clausurados -con interregnos antidemocráticos de por medio- en la década de 1970 con el golpe de Estado que derrocó a Allende (137-139). Conviene precisar que, a la luz de las novelas citadas, quien dice clase media, alude a académicos universitarios, a comerciantes detallistas, a empleados públicos, a linotipistas, a periodistas colegiados, a profesores normalistas y a obreros calificados, entre otros funcionarios asalariados. Se trata de un grupo heterogéneo de individuos que comparten el haber sido educados en un sistema de educación pública laico y pluralista, y, sobre todo, el haber estado comprometidos con las ideas de la centro izquierda chilena (radicalismo y socialismo).

${ }^{5} \mathrm{La}$ novela social es aquella que, escrita entre 1930 y 1940, impugna los órdenes sociales clasistas y exalta las utopías frente-populistas. Goic precisará que aquello que denominamos novela social, corresponde a la segunda generación del periodo superrealista. Según Goic, esta segunda generación superrealista, o generación de 1942, se desenvuelve como una generación polémica, pues entiende la literatura como una herramienta de lucha político-social. En el nivel formal -sentencia el crítico chileno- los escritos de esta generación ostentan las características del realismo social (217). Retóricamente -adelantemos- esta evocación nostálgica se manifiesta a través de recursos tales como: (a) estilización de los textos literarios del canon chileno que aceptan ser leídos como testimonios de la solidez ética y la cultural de las capas bajas y medias de dicha época (se miman metáforas y giros lingüísticos), (b) incorporación de esos escritos como intertextos (leídos y comentados por los narradores/ personajes de las novelas de los hombres grises), y (c) rescate arqueológico de los escenarios urbanos recurrentes de aquellas novelas (conventillos y mercados). 
En lo que sigue, mi objetivo es establecer una "anatomía de la escritura" del hombre gris. Con este propósito, paso revista a dos novelas: Machos tristes, de Darío Oses, y El color de la piel, de Ramón Díaz Eterovic. En mis revisiones, pongo especial énfasis en las implicaciones ideológicas de estos gestos "memoriosos".

\section{HOMBRES GRISES (CUERPOS MENGUADOS)}

¿Quiénes son los hombres grises que emergen en la narrativa de las nuevas generaciones? Antes de cualquier elucubración, esbozo su perfil sumario:

(1) el hombre gris (narrador o personaje) se constituye como un yo nostálgico en oposición a ese otro alienado del presente que se deja cooptar por las tramas del mercado;

(2) el hombre gris delimita sus coordenadas espaciales y temporales a partir de un movimiento que consiste en restarse de los no-lugares del paisaje contemporáneo para, así, retrotraerse a una geografía urbana cruzada por "grandes alamedas," fábricas, escuelas y hospitales públicos";

(3) el hombre gris fija posiciones lingüísticas a partir del rechazo de los anglicismos snobs y el rescate riguroso de viejos adagios populares-criollos ${ }^{8}$.

Desde una perspectiva "afectiva", la enunciación del hombre gris (enunciación volteada hacia la ensoñación de un pasado fenecido), aparece casi siempre transida por culpa, la melancolía y el tono elegiaco.

"Escritura culposa" primero, porque ella es el escenario donde el sujeto se reconoce a sí mismo como protagonista de su propio fracaso (por ejemplo, en las escrituras de Spotorno, el hombre gris es el "pusilánime" que carga la cruz de haber capitulado en la contienda ideológica de la década de 1970: "o sea (...) somos todos unos fracasados. Cada uno de nosotros quebró su sueño. Y

${ }^{6}$ Los paratextos de las novelas comentadas son reveladores sobre este punto: Darío Oses se presenta como "nacido y críado en un Santiago transparente, apacible, anterior al smog y a la modernidad" (solapa), y Radomiro Spotorno dedica su texto a "mi generación, que lo quiso todo" (1994: 7).

${ }^{7}$ El narrador de Machos tristes recuerda que "la Universidad de Chile (...) fue un punto de encuentro de todos los estratos y credos. En ella aprendieron a convivir hombres procedentes de los más diversos estratos sociales" (Oses, 1991: 53). Y, el protagonista de La secreta guerra santa de Santiago de Chile, siempre recuerda "que su padre había sido medio radical socialistoide, mucho Aguirre Cerda, votando por Allende como mono porfiado, mucho Frente Popular, mucho pueblo de Chile" (De la Parra, 1989: 13).

${ }^{8}$ En La secreta guerra santa, su autor, De la Parra, se anuncia como quien "reconstruye los mitos de la clase media chilena" (contra-portada). Y, en La patrulla de Stalingrado, la contratapa avisa que se trata de "una novela delirante (...) una delación del secreto de lo que hablan los hombres". 
para no vivir ese fracaso se mato Cacarlos. Para vivir lleno de vida y de amor" (1994: 104).

"Escritura melancólica" después, porque, en lugar de lanzarse hacia la experimentación formal de la neovanguardia (Diamela Eltit, Guadalupe Santa Cruz) o a los territorios spanglish del grupo McOndo (Alberto Fuguet, Sergio Gómez), el hombre gris se abandona al remedo autocomplaciente de las imágenes de un pasado irrecuperable, conocido a través de la tradición literaria de la novela social chilena. Por ejemplo, en Machos tristes, sus personajes no olvidan el tiempo en que "fue la Universidad de Chile la que después marcó el tiempo y el ritmo de la vida en la ciudad" (1994: 71). O, en La patrulla de Stalingrado, uno de los protagonistas confiesa que "siempre al cruzar el Mapocho hacia el norte me da la impresión de volver a los tiempos en que mis padres eran jóvenes, con autos gordos y tranvías" (1994: 21).

Y, "escritura elegiaca”, también, porque el cuerpo cívico; es decir, la ciudad, sus instituciones, sus leyes y sus habitantes, son perpetuamente figurados como miembros de un organismo menguado y en pleno proceso de descomposición. Aquí, la ciudad y sus conciudadanos, tal como la edificaron los líderes de la antigua izquierda, son el cuerpo sobre el cual el neoliberalismo "mal-habido", importado por el militarismo y consolidado por los gobiernos de la Concertación de Partidos por la Democracia, imprime sus huellas de corrupción y de muerte: "el mundo está podrido y se cae a pedazos" (Díaz Eterovic, 2003: 53), y "la ciudad quedó domesticada por tres lustros de férrea dictadura, sojuzgadas sus noches por el Toque de Queda" (Spotorno, 1994: 29)9 .

A la luz de los datos, el lector se preguntará: ¿de qué manera dialogan estos relatos de los hombres grises con las novelas sociales de, por ejemplo, Nicomedes Guzmán, autor de una novela de "formación proletaria" cuyo título inspira el de este ensayo: Los hombres oscuros?, ¿acaso son estos relatos sólo sus remedos

${ }^{9}$ Desde una perspectiva ideológica, esta mirada nostálgica ha sido criticada -a mi juicio con justa razón- por Jaime Lizama (2007). En su La ciudad fragmentada, escribe: no es muy difícil o complicado afirmar que la ciudad de Santiago en el transcurso de las décadas del 1940 al 1960 no existía como problema o negatividad, al punto de complicar la vida de sus habitantes; en cierta forma, la ciudad se concibió y planificó en el Centenario de la República y se extendió, edificó y modernizó su centro cívico y comercial en los gobiernos radicales. No deja de ser extremadamente llamativo que publicaciones recientes sobre Santiago y sobre su memoria elogien no sin cierta nostalgia ese periodo de la historia y desarrollo de la ciudad en contraposición con la realidad salvaje, caótica y poco amigable del Santiago actual. Sin embargo, lo que siempre queda fuera de estas hermenéuticas del recuerdo es precisar que la ciudad de Santiago a la cual se alude es, específicamente, su exclusivo centro cívico (Lizama, 2007: 17).

La posición de Lizama no sólo choca con las novelas aludidas en este estudio sino, también, con una ensayística que comparte tal fascinación por el pasado: Marco Antonio de la Parra (La mala memoria, El cuerpo de Chile) y Tomás Moulián (Chile actual: anatomía de un mito). 
posmodernos? Considero que los relatos de los hombres grises se estructuran como residuos hipertextuales de las novelas sociales: aquellos no sólo aprenden en estas la cartografía del Santiago sepultado por la dictadura y olvidado por la transición; también, las novelas sociales son modelos de comportamiento cívico por los que se enjuicia el presente ${ }^{10}$. Anótense, entre otros, tres puntos de contacto entre relatos de hombres grises y novela social.

Primero, si en el relato de los hombres oscuros los individuos "se forman" como sujetos comprometidos con la comunidad y reafirman su virtud en la lucha de clases (sus retóricas romancescas, o de bildungsroman, ungen héroes proletarios), en la novela de los hombres grises, la arena política es el escenario donde los ciudadanos comunes revelan su egoísmo malsano (vástagos de los héroes de antaño); sus retóricas irónicas anuncian el advenimiento del sparagmos o certeza de que cualquier causa "salvadora" está condenada, de antemano, al fracaso ${ }^{11}$.

Segundo, de esto se sigue que mientras el relato de los hombres oscuros discute las políticas públicas que rigen la convivencia urbana (e.g. la "Huelga de la carne" de 1905, mentada por Sepúlveda Leyton en su Hijuna), la novela de los hombres grises indaga en la manera en que las pequeñas derrotas privadas explican las posiciones asumidas en la esfera pública (uno de los personajes de Spotorno confiesa que "el 11 de septiembre de 1973" no salió a la calle porque “me lo pasé 'encamado' con una señorita” (1994: 187).

Tercero, si en relato de los hombres oscuros los obreros son "los vigorosos músculos" de la ciudad (e.g. "tierra preñada" es una isotopía recurrente en los relatos de Guzmán), en la novela de los hombres grises sus habitantes son "las células muertas" de su "proceso de descomposición": "porque los comunistas vamos siempre jodidos. Hasta tenemos vergüenza de reconocer que lo seguimos siendo" (Spotorno, 1994: 29).

\section{RECONSTRUIR LA CIUDAD (EN LA MEMORIA)}

¿Qué ciudad añoran los hombres grises? ¿Cómo la representaron, antes que ellos, los novelistas sociales? Sirva abrir un breve paréntesis histórico: blandiendo

${ }^{10}$ Los narradores/personajes de las novelas aludidas continuamente están leyendo desde el presente relatos del pasado: en Díaz-Eterovic, Heredia lee a Guzmán; en Oses, Manolo esboza remedos de Rojas; y, en Spotorno, González Vera es reconocible.

${ }^{11}$ Uno de los personajes de La patrulla confiesa: "Sí. La democracia nos quita el paraguas. El financiamiento y la solidaridad internacional se desplaza del llamado 'sistema académico informal', creado durante la dictadura, al ámbito gubernamental y productivo" (1994: 20). La post-dictadura parece ser -de manera paradójica- el espacio donde se desvanece la posibilidad de fundar colectivos que impugnen los poderes autoritarios. Aquí, La patrulla ... coincide con la tesis de Tomás Moulián y el transformismo político. 
el estandarte del nacionalismo y la educación pública, los gobiernos del Frente Popular, de la Revolución en Libertad y del Socialismo a la Chilena (19381973), abrazaron la idea de otorgar a las capas medias carta de ingreso a la vida cívica de la Nueva Extremadura ("Gobernar es educar", reza el lema de la época). Así, pues, desde una perspectiva laica, liberal e incluso populista (Rama dixit), el Estado chileno se propuso destruir los signos que el colonialismo europeo, en sus distintas manifestaciones, imprimió en la cartografía citadina entre los siglos XVI y XIX.

Fascinados con las ideas progresistas del urbanismo social, doctrina difundida en Chile por el arquitecto vienés Karl Brunner (1898-1960), los caudillos de tales regímenes populistas impulsaron, justamente, un plan de reforma urbana, cuyo propósito era, literalmente, abrir las "grandes alamedas" para permitir el avance de una clase media compuesta por comerciantes, docentes normalistas, obreros, técnicos y profesionales liberales -hasta entonces postergada a la marginalidad de arrabales y conventillos ${ }^{12}$.

Los urbanistas sociales del frente-populismo idearon extensas avenidas arboladas que permitieran el acceso del trabajador anónimo al otrora vedado centro cívico; imaginaron magníficas ramblas que facilitaran el intercambio de mercancías; proyectaron plazas para que se celebraran eventos artísticos; maquinaron modernas redes de electricidad y alcantarillado que garantizaran la salubridad de las barriadas marginales; soñaron con transformar los cañaverales del río Mapocho en un cordón industrial (proyecto, finalmente, abortado). También, son ellos quienes programaron la construcción de las más de 4.000 escuelas de hormigón armado, donde los maestros normalistas de las escuelas metropolitanas transmitieron a las nuevas generaciones el humanismo de Andrés Bello ("la ciudad hablaba, entendía y gratificaba a los hombres que vivían en ella” (Oses, 1991: 71).

No olvidemos tampoco que, influenciado por la fisiología moderna, el añorado urbanismo social de Brunner imaginó la ciudad como un saludable organismo vivo ${ }^{13}$. Entre las líneas de las cartografías, las columnas de prensa,

\footnotetext{
${ }^{12}$ Como explica el historiador Armando de Ramón (2000): “en 1934 el citado urbanista Brunner (...) preparó un 'Anteproyecto regulador de la comuna de Santiago' que fue la base para el estudio definitivo que hizo el arquitecto Roberto Hummers. Este concluyó su trabajo en 1939 elaborando un plan que fue aprobado ese mismo año, es decir, bajo la presidencia de Aguirre Cerda" (222).

${ }^{13} \mathrm{La}$ visión de la ciudad como cuerpo jerarquizado, propuesta por Brunner, tuvo aciertos y errores; entre los aciertos, destaca la convicción por iniciar "una modernización de todos los sectores de Santiago, extendiendo esta acción a los barrios modestos" (De Ramón, 2000: 222); y, entre los errores, su rigidez: "un barrio netamente obrero debe ser mantenido y limitado como tal" (Brunner cit. en De Ramón, 2000: 222).
} 
los escritos académicos, los mapas, los planos y las maquetas del urbanista vienés, surge una auténtica alegoría de la vitalidad. En las cartografías de la época, leemos: las instituciones estatales (lideradas por la Universidad de Chile) serían la cabeza que revelaría los derroteros de la modernidad; los obreros, los músculos de la actividad industrial; las grandes alamedas, las arterias por donde circularían las mercancías; las plazas y los parques, los pulmones donde se ventilarían las ideas políticas; el río y los canales y los zanjones, el intestino que evacuaría las heces; y los lupanares (salubres y controlados como todos los miembros de este cuerpo), las zonas erógenas a través de los cuales el pueblo liberaría sus pulsiones libidinosas ${ }^{14}$.

Conviene decir que la novela social es el correlato de este proceso de modernización urbana: más allá de su consabido valor documental (Morand, 1977: 139-41), autores como Guzmán o Sepúlveda Leyton tuvieron la capacidad de crear un repertorio de metáforas que les permitió dejar atrás la retórica naturalista y, por ende, consiguieron representar las "utopías" cívicas que el frente-populismo no siempre logro concretar. Sirva anotar algunos ejemplos consabidos donde se evidencia cómo la ciudad proletaria es retratada corpóreamente: "Por las arterias del suburbio, la sangre corre a torrentes" (Guzmán, 1995: 37), "La sangre me corre a torrentes por las arterias" (Guzmán, 1995: 38), "Pienso que debería ingresar a alguna institución política obrera. Sobre todo ahora que la sangre me corre como torrentes por las arterias y los pulmones se me ensanchan" (Guzmán, 1995: 39), "Tierra que chupa la vida de los proletarios caídos en la sangre de los cuerpos que fuyen" (Guzmán, 1995: 73). O, "Los suburbios, bajo el otoño, frente a la mirada turbia del tiempo, arrugaban el ceño, estiraban su osamenta crujiente, abierto el pecho franco" (Guzmán, 1964: 259; todas las cursivas son mías). El uso de expresiones tales como "torrentes", "arterias", "pulmones", "estirar" y "abiertos" asemeja estos frisos urbanos a los modelos corpóreos de nueva fisiología: disciplina que concibe el organismo como un sistema abierto de flujos (circulación, respiración), y no como un mecanismo cerrado (cfr. La ciencia experimental, de Claude Bernard, publicado en 1878 y canonizado más tarde, por Zola, como el texto de cabecera del naturalismo).

Así como las novelas de los hombres oscuros describen alegóricamente el levantamiento de este cuerpo cívico, las novelas de los hombres grises cuentan su mutilación. A juicio del narrador/protagonista de La secreta guerra santa: "La calle Independencia se le hizo más pesada y sucia. Pensó en su padre

${ }^{14}$ No es azaroso que, en la tercera unidad del seminario que Brunner impartió en la Universidad de Chile, un lugar preponderante lo ocupaba la "fisiología urbana” (Pavez, 1996: 38). 
contándole por enésima vez en los deseos de Gómez Millas, cuando era rector de la Universidad de Chile, de construir una gran ciudad universitaria en la Vega Central llevándose los intestinos de la capital, el vientre de Santiago, más al norte" (1989: 18). Ciertamente, al emplear la metáfora de la "mutilación" estoy haciendo eco de la isotopía que articula de cabo a rabo los discursos urbanos nostálgicamente re-citados por las novelas de los hombres grises. La ciudad es un cuerpo, nos recuerdan los camaradas de La patrulla..., aunque ahora aquejado por las patologías de la globalización: "cuando el cementerio se llene (...) habrá una reforma urbana y le pasarán las máquinas por encima y construirán un estadio o una población y todos los muertos se irán a la mierda" (13). Enfrentados a un presente en ruinas, los hombres grises hacen de las citas al urbanismo y la novela sociales, un espacio afectivo donde capear la alienación y las condiciones de anomia generadas por el mesianismo neoliberal: “ ¡Vivan Clotario Blest y Recabarren! Porque sin locos ni santos este país no sería más que un sórdido boliche atiborrado de mercaderías" (Oses, 1991: 257); "Cacarlitos necesitaba creer, creer en la democracia, creer en el socialismo, creer en la verdad, creer en la justicia, creer, creer, quién sabe en qué otras huevadas. Será huevón" (Spotorno, 1994: 21).

En los apartados que siguen (dedicados al análisis de las novelas Machos tristes y El color de la piel), resulta interesante contraponer, por una parte, el corte pasado/presente que establecen las novelas de los hombres grises y, por otra, algunos datos "duros" relativos a la expansión de Santiago entre 1940 y 1970 -tal como son documentados en ensayos históricos ${ }^{15}$. Mi ejercicio de análisis literario no pretende "exhibir" la falacia encerrada en las novelas de los hombres grises. Muy por el contrario, apunta a comprender empáticamente la estructura de sentimientos -como diría R. Williams- que subyace a tales visiones de la ciudad de antaño y, además, a discutir sus condiciones de posibilidad.

\section{HACERSE HOMBRES (EN LAS RUINAS DE LA UNIVERSIDAD)}

Un primer gajo que se desprende de la mentada alegoría de la mutilación, eclipse finisecular de la alegoría de la vitalidad que iluminó el paisaje frentepopulista, es Machos tristes, de Oses. El argumento de esta novela ambientada en el Santiago de Chile de 1982 y dividida en 52 capítulos breves (instantáneas de un Santiago sitiado por la dictadura), reza que Manuel es un viejo combatiente

\footnotetext{
${ }^{15}$ Ensayistas como De Ramón y Lizama evidencian las limitaciones de la ciudad frente-populista: ambos indican que ya en 1952, "entre los que vivían en conventillos, cités y casas sub-arrendadas por piezas y los sectores que vivían en callampas comprendían sobre 400.000 habitantes, cifra cercana al 37\% de la población de Santiago" (Lizama, 2007: 30).
} 
de las luchas frente-populistas, mientras Martín es un muchacho descreído de las utopías de antaño. Ambos machos mal-habidos cumplen la condena de trabajar en la rectoría de una Universidad de Chile, hoy día, convertida en una máquina productora de discursos placebo (jerigonzas académicas serviles al autoritarismo). De modo autoflagelante, estos funcionarios de "mediopelo" acortan los días ensayando una serie de borradores novelescos donde recíprocamente se enrostran sus miserias. En este diálogo zahiriente, Manuel reconoce en el escepticismo de Martín las consecuencias del narcisismo de sus congéneres. De manera contraria, Martín identifica en Manuel a un padre vergonzantemente ingenuo. Más allá de las simpatías personales, el lector reconoce en estos personajes a dos huérfanos de los proyectos políticos del Chile contemporáneo.

Manolo y Martín suplen su sentimiento de orfandad a través de la escritura memoriosa. Sus borradores, redactados en clave realista, recogen las anécdotas, las canciones, los chistes, las consignas, los cuentos, las canciones, los discursos, las fantasías, las historias, las jugarretas, los libros, los mitos, los murales y las revistas, de una época donde la universidad marcaba el pulso de la vida citadina. Estos "rescoldos lingüísticos" constituyen un orden simbólico o, lo que es igual, una cadena de significantes, que re-sitúa la escritura de estos vencidos en un presente desfigurado por la amnesia.

Las imágenes anatómicas son la figura central de los borradores nostálgicos inscriptos en la novela -piénsese, sin ir más lejos, en expresiones tales como "músculos, tendones y arterias santiaguinas" (45), "proletarios invencibles" (45) y "sangre del pueblo" (52). Merced a estas metáforas y epítetos, los narradores (alternadamente, Manolo, Martín y una voz omnisciente que los espía por el ojo de la cerradura) nos conminan a comprender la historia santiaguina como un irreversible proceso de jibarización del cuerpo cívico ${ }^{16}$. Si en el allálentonces la urbe es un vigoroso organismo vivo, en el aquilahora será un cuerpo, en todo

${ }^{16}$ ¿Jibarización? Efectivamente. Denomino así al conjunto de políticas culturales por las cuales el militarismo, por una parte, transforma las instituciones civiles en maquinarias productoras de discursos que, cuando no son ancilares, resultan obsoletos ante las emergencias citadinas. Y, por otra, confina a los ciudadanos al ostracismo de guetos, ya sea sociales o profesionales. Como es de suponer, esta categoría alude a las medidas "dóciles" (bandos, decretos o leyes), no a las "represivas" (toque de queda o tortura).

En su comentado Alegorías de la derrota: la ficción post-dictatorial y el trabajo del duelo, el crítico brasileño Idelber Avelar (2000) analiza cómo se da este "fenómeno" en las universidades latinoamericanas sometidas a los regímenes autoritarios de la segunda mitad del siglo XX, especialmente, en las argentinas, brasileñas y chilenas. Entre otras síntesis pertinentes, el crítico señala que el advenimiento del militarismo trocó el carácter de la universidad: desde institución generadora de pensamiento humanista hacia empresa productora de técnicos (110-20). De Bello a Brünner, complementará más de alguien. 
caso, mutilado. Para rubricar esta aseveración, analizo dos pasajes representativos de las diatribas de Manuel y Martín. Leamos esta postal anatómica de la vida universitaria hacia fines de la década de 1946, firmada por el propio Manuel:

Como lo hicieron las iglesias con sus campanarios durante la colonia fue la universidad la que después marcó el tiempo y el ritmo de la vida en la ciudad, y además le inoculó una sustancia nueva porque no solo engranajes de relojería operaban en el altillo. Los cabros del ITUCH renovaron el arte dramático que hasta entonces se reducía a los galanteos de Alejandro Flores. Más allá Domingo Santa Cruz organizaba orquestas (...), mientras los maestros de danza exiliados de la Alemania Nazi preparaban las coreografías de Carmina Burana y de la Mesa verde (...) todo eso, conciertos, estrenos, sueños, manifiestos, pasaban a ser parte del lenguaje con que la ciudad hablaba, entendía y gratificaba a los hombres que vivían en ella (71-72; las cursivas, cuando no designan los títulos, son mías).

Desde una perspectiva de género, llama la atención que las representaciones de la Universidad de Chile y sus funcionarios evoquen siempre la anatomía de un cuerpo masculino: "universidad que marca pulsos" o "universidad que inocula sustancias". Manolo y Martín narran con fervor que, entre 1940 y 1973, los distintos discursos que convergen en el "texto programático" de la izquierda chilena (la ley de instrucción primaria, el periodismo militante de El Siglo, el realismo socialista, el sindicalismo y el urbanismo social, entre otros), ayudaron a fortalecer la convicción de que el cuerpo cívico debía ser animado por los "impulsos eléctricos" o "destellos de luz" emanados desde la Casa de Bello: el saber generado en el aula universitaria (cerebro de la ciudad) se transmitiría hacia una red de escuelas normales (suerte de médula espinal), mientras los profesores secundarios (genuinos neurotransmisores), penetrarían con su conocimiento en la oscuridad de las barriadas proletarias (otrora, órganos atrofiados por la miseria). La Universidad de Chile -insisten los personajes de Oses- habría permitido establecer, en su regazo, "una jerarquía basada en la capacidad y el conocimiento, frente a la cual no prevalecía ningún privilegio derivado de la fortuna y el abolengo" (1991: 53). De ahí que en los claustros universitarios pudiera "verse a trabajadores de muy distinto rango, desde empleados y jefes administrativos hasta académicos y auxiliares, todos con sus cascos puestos" (1991: 48).

Desde mi perspectiva, en cambio, infiero que Manolo y Martín añoran menos la institucionalidad frente-populista que la retórica por la que esta fue narrada en la tradición de la novela social. Me explico. Según dicha retórica, el 
sujeto masculino se constituye en el ejercicio de sus derechos cívicos (educación pública, militancia política...). Hoy día, en cambio, tras la clausura de esos espacios públicos, la constitución del sujeto masculino se debe llevar a cabo en otros espacios: el mercado (que sólo reconoce guarismos económicos), o la alcoba (donde desnudamos nuestras debilidades). Luego, la tristeza de estos machos, a mi juicio, no tiene que ver con la nostalgia de un programa político sino, más bien, con la pérdida de un tipo de discurso que, a través de sus ficciones literarias, otorgaba la chance de "hacerse hombres" más allá de la alcoba y más acá del mercado.

Anoto de manera suplementaria que en las descripciones memoriosas de nuestros machos tristes, las metáforas anatómicas - "proletarios musculosos empuñando hoces y martillos" (45), "obreros afanados en criar un nuevo Chile" (48) o "necesidad de extirpar el imperialismo" (52; las cursivas son mías) asemejan las descripciones del antiguo cuerpo cívico a los murales callejeros de la Brigada Ramona Parra (frisos de factura didáctica que, durante las décadas de 1960, 1970 y 1980, exhiben las utopías vindicativas de la izquierda santiaguina mediante una estética que releva las aptitudes físicas de sus militantes hombres ${ }^{17}$ ). Para mejor comprender esta aseveración, escuchemos, entonces, en clave plástica, lo que Manolo nos susurra al oído: "[Nuestros correligionarios] Confiaron en que legiones de guerrilleros de miradas altivas, iguales a las del 'Ché' Guevara, se multiplicarían en barricadas, mientras escuadrillas de palomas blancas neutralizarían el ataque de los helicópteros y los Hawker Hunter" (45).

Cerrado el paréntesis de género, cabe preguntarse ¿qué ocurre con el aquil ahora de la dictadura y su neoliberalismo salvaje? Escuchemos, ahora, las lamentaciones de Manolo:

\footnotetext{
${ }^{17} \mathrm{Al}$ igual que en los borradores de los machos tristes de Darío Oses, los muralistas de la Brigada Ramona Parra pintan en la clandestinidad una serie de frisos que, merced a la "hipérbole anatómica" plasma épicamente la marcha emancipadora de la multitud santiaguina. Me interesa llamar la atención sobre las cualidades didácticas de este lenguaje plástico, utilizado en intervenciones callejeras realizadas en la periferia de la ciudad. Este tipo de representaciones -a decir del propio Oses, "coloreadas como las láminas de los libros de anatomía" (45)- poseen un carácter ontológico. Es decir, ellas son el cuerpo gráfico donde las capas bajas y medias encarnan el espíritu de sus ideas políticas. Los dibujos de rostros iracundos, torsos musculosos, brazos vigorosos y manos empuñando mazos, evocan el contenido de las ideas marxistas sobre la multitud y el trabajo, pero despojado del fastidio filosófico de sus argumentaciones. En estas ilustraciones, en cambio, prima el lirismo telúrico de la poesía popular. En la ciudad gris (o, "de color arratonado", como dice Oses), mientras el politólogo habla, por ejemplo, de fuerza de trabajo en términos crudamente teóricos, el brigadista proletario cubre las murallas con las siluetas de trabajadores de muy distinto rango. En una esquina, un proletario empuñando la hoz y el martillo; en un bloque de departamentos, una paloma desgarrándose en la mano de un burgués; en la aridez del concreto, un maestro volantinero derribando helicópteros con sus pavos y sus ñeclas.
} 
La ciudad (...) se ha convertido en una gran feria libre donde el diálogo acerca de los libros, la música y el teatro se cambió por el persistente vocear de mercaderías (...) [La Universidad] No se distingue en nada de otras reparticiones públicas donde la principal preocupación de todo el mundo es conservar la pega y para eso nada mejor que obedecer, acatar, bajar el moño (72; las cursivas son mías).

Si las metáforas anatómicas re-inventan la escritura del pasado, las metonimias jibarizan las letras del presente. Expresiones tales como "ciudad cuyo único discurso autorizado es el voceo de las mercancías" o "cuadrilla de empleados que vive en un perpetuo agache de moño", diagraman el aquil ahora del militarismo como el espacio/tiempo de los cuerpos menguados. La reiteración de estos "tropos de la mengua" es síntoma del advenimiento de una nueva definición de cuerpo cívico. Se trata de un trueque entre un urbanismo anclado en el socialismo (afín al imaginario frente-populista) y otro inscrito en el paradigma del capitalismo tardío (cercana al proyecto de los "Chicago Boys"). Si el primero examina el cuerpo cívico como un organismo jerarquizado (la academia civilizará los arrabales), el segundo lo reconoce como un ente cuya salud depende de los guarismos de la ley de la oferta y la demanda (el mercado regulará la academia).

\section{EL COLOR DE LA PIEL: ENVEJECER (EN UNA CIUDAD ARREBATADA)}

Un segundo gajo que se desprende de la alegoría de la mutilación del cuerpo cívico soñado por los caudillos frente-populistas, emerge en la narrativa detectivesca de Ramón Díaz Eterovic. No obstante -a diferencia de lo que ocurre con su contemporáneo, Darío Oses-, su proyecto de escritura está más interesado en recuperar los enclaves de la bohemia de los años 40 que en componer elegías ante las ruinas de la Universidad de Chile. De acuerdo con este plan arqueológico, las calles Bandera y Puente (ayer, repletas de cabarets y hoteles galantes; hoy día, atiborradas de tiendas de ropa usada, comercios clandestinos e inmigrantes peruanos indocumentados), serán el axis mundi de las peripecias del detective Herida, protagonista de casi todas las novelas publicadas por Díaz Eterovic. En lo que sigue, me demoro en una de sus entregas recientes: El color de la piel.

Heredia, cual flâneur, contempla melancólico el casco antiguo de ese Santiago de la época republicana: ahora, eso sí, convertido en "espectáculo de actores callejeros, pintores, hombres estatuas, predicadores y comerciantes. Sinfín de rostros sudorosos" (15). En su ocioso deambular, Heredia constata cómo el 
garbo y las lentejuelas de las bailarinas y mafiosos de antaño se ha marchitado, dando origen a una escena urbana a medio camino entre el expresionismo y el grotesco: "observé a los clientes de aspecto patibulario" (30), "El paseo Ahumada estaba poblado de estatuas humanas: vaqueros, soldados romanos, filósofos griegos, vampiros, discóbolos, astronautas, fantasmas de túnicas blancas" (42), "Caminé y luego de un rato comencé a ver a los hombres que yacían en las veredas, cubiertos de frazadas y grandes trozos de cartón” (58).

En el Santiago actual, Heredia se ve a sí mismo como el último sobreviviente de un paraje que le fue arrebatado: "El peruano me miró de reojo" (16), "El tendero me miró desconfiado" (32), "los clientes prodigaban sus miradas de perros cachondos" (30). De esto se sigue que, al igual que en la transferencia psicoanalítica, el acto de fisgonear al otro implica, complementariamente, mirar los propios fantasmas: "su imagen se convirtió en un recuerdo" (18), "Esta noche reconocí en su rostro el rostro de mi soledad" (18).

La mirada devuelta por ese otro envía a Heredia hacia la fase psíquica de la nostalgia y de la melancolía (Kristeva, 1995: 4-5). Las huellas que las políticas neoliberales inscriben tanto en los edificios como en la retina de sus transeúntes, despiertan en la psiquis de Heredia el deseo de refugiarse en el recuerdo halagüeño y fantasioso del pasado frente-populista. El "mal de ojo" que azota a Heredia, en consecuencia, es uno: mirar melancólicamente. O, si se prefiere, enquistar bajo la retina las astillas de un pasado irrecuperable: "la vieja $\mathrm{y}$ traicionera mirada no tiene horarios. Al menor descuido deja unas palabras o un recuerdo en los bolsillos" (18).

Desde una perspectiva formal, se impone indicar que esta visión pesimista de la urbe está reforzada por un tejido intertextual de textos poéticos cuya matriz discernible es memento mori. Recitando versos de Pessoa o Vallejo, el detective traza las coordenadas espacio temporales que el sujeto melancólico (hombre gris) ocupa en el tinglado urbano; es decir, una posición liminar en los discursos de la globalización (cultura pop, neoliberalismo y políticas conciliadoras). Expresiones tales como "Estás solo. Nadie lo sabe. Calla y finje" (Pessoa cit. en 39) o "Moriré en parís con aguacero un día del cual ya tengo recuerdo" (Vallejo cit. en 120), insisten que se trata de un sujeto que no encuentra resignación ni sosiego. Parafraseando a estos poetas, Heredia ensaya sus propios versos: "Envejezco, lleno de cigarrillos mis pulmones, mis piernas sufren al subir las escaleras del Metro; al final del día, rendido de copas y malos pasos, duermo para espantar la soledad" (29).

Vistas así las cosas, se hace evidente que la biografía del sujeto melancólico, Heredia, se construye como una cadena de signos de dislocación, inestabilidad y pérdida de los afectos, cuyo escenario es un presente inicuo. En esta cadena, 
la voz del narrador se disuelve en una eterna elegía: "Sólo queda la repetición de algunos gestos conocidos y las burlas de un cuerpo cansado. Los golpes duelen el doble, las resacas me desprenden la piel y no consigo revivir los sentimientos de antaño" (39).

Si la mirada de Heredia es una mirada melancólica, no resulta aventurado ensayar una interpretación alegórica y nacional de su biografía (es decir, leer las cicatrices de su cuerpo y su memoria como letras descalzadas del destino de la nación). En un sentido figurado, Heredia representa la mala suerte de la clase media-baja: guacho de nacimiento, en plena década de 1940 (la época de Aguirre Cerda), es enviado a un orfanato, donde recibe cuidados pediátricos básicos (el pueblo rescatado de la indigencia). Luego, asiste al Internado Nacional Barros Arana y es reformado en la tradición laica, liberal y republicana de la educación pública. Con la formación recibida, ingresa a la carrera de Derecho en la Universidad de Chile (consiguiendo, así, la movilidad social). A poco andar, viene la Batalla de Chile (Golpe de Estado), la universidad es intervenida y Heredia queda a la deriva (orfandad social). De ahí en más, la carrera detectivesca (marginal a la justicia "oficial") será un espacio desde el cual ajustará cuentas con el pasado (memoria nacional).

¿Qué formas emplea esta alegoría identitaria para expresarse? ¿Cuáles son sus modelos retóricos? Con las astillas del pasado que enquista, melancólicamente bajo su retina, Heredia reconstruye la ciudad perdida. El resultado de este proceso de creación es una cartografía citadina (escenario de crímenes y persecuciones), cuyo verosímil está más cerca de la novela social chilena de la década de 1940 (Nicomedes Guzmán), que de los manuales de historia nacional. Propongo, entonces, que de la novela social recoge el imaginario popular que anima sus representaciones (conjunto de prejuicios éticos y estéticos sostenidos por las clases "inferiores").

La mirada de Heredia, cual máquina de rayos, ilumina sólo aquellos espacios señeros de la memoria que, cuales quistes, se resisten a ser disueltos por el neourbanismo amnésico (bares, conventillos, ferias libres, fuentes de soda, hoteles galantes, mataderos y mercados persa ${ }^{18}$. Sus escenas urbanas, por cierto,

\footnotetext{
${ }^{18}$ De acuerdo con esta afirmación, reconstruyo la bitácora del flâneur: 7:00. "con el sol en las entrañas, lavo mi rostro y me visto con toda la esperanza que poseo" (29). 7:45. Salgo a la calle bandera, porque y camino "por el barrio escudriñando en los escaparates de las tiendas y apreciando el aroma de las frutas exhibidas en los puestos ubicados frente al Mercado Central" (50). 9:00. Observo y me doy cuenta que ahora "Hay más tiendas de ropa usada, más cafés atendidos por jovencitas semidesnudas, más tiendas chinas" (23). 12:00. "[Junto a Anselmo, el suplementero] Nos encontrábamos en el restaurante 'Central' de la calle San Pablo. Un mozo nos dijo que se podía pedir congrio frito o lomo a lo pobre" (22). 13:00. "Terminamos el almuerzo y nos encaminamos hacia una sucursal hípica del barrio. El lugar parecía un avispero, lleno de tipos ansiosos de besar
} 
están habitadas por una galería de personajes decadentes descritos de manera grotesca y/o paródica: "familias que cenan o beben una triste merienda de té y pan con margarina (...) parejas de ancianos que se miran con callado hastío (...) hombres de torsos desnudos que juegan solitario (...) seres anónimos que día a día se levantan a trabajar (...) trozos de carne que resisten con la resignación de un caballo de feria" (15). Estos personajes, eso sí, actúan rutinas que eclipsan la luz veleidosa de los eslóganes publicitarios que destellan en el otro lado de la urbe, la de loops y de freeways. Eclipse por cuanto dichos personajes son el remedo desajustado de las fantasías compensatorias de los hombres grises.

Para los críticos literarios, Heredia sólo les debe a sus colegas anglosajones. Poco se ha dicho de su ascendiente chileno. En su representación del vaudeville callejero, nuestro paseante realiza una estilización, o re-apropiación depurada del lenguaje propio de otro autor (Nicomedes Guzmán). Esbocemos algunas deudas de Heredia con las letras criollas. Mi comparante es el relato Los hombres oscuros, memorable cuadro vivo de la vida de los conventillos. Esta novela está narrada en primera persona por Pablo Acevedo, un muchacho que reniega de su clase para comprometerse con la lucha proletaria. En primer lugar, en ambos textos la sintaxis de las descripciones es escueta y paratáctica; semejante a las didascalias de un guión cinematográfico: "Las mujeres borrachas chacotean. Agarrones. Risas beodas. Carcajadas estúpidas. Rostros agitados" (Guzmán, 1995: 26) versus "Conversaciones en voz alta, risas, ilusión de una reunión festiva, un halo de tristeza cubría el lugar” (Díaz, 2003: 80). En segundo lugar, ambos narradores ponen énfasis, merced al claroscuro, en el carácter espectral de los hombres grises y sus casas-pocilga: "La luz de la vela le da a su rostro pálido un matiz espectral" (Guzmán, 1995: 32) o "la luz de la vela mimetiza el rostro de las mujeres" (Guzmán, 1995: 81) versus "A través de unas tímidas ventanas salía una tímida luz del interior del galpón [conventillo]" (Díaz, 2003: 102) o "el neón de la calle contigua al conventillo la rodeaba de un aspecto fantasmal” (Díaz, 2003: 107). En tercer lugar, ambas novelas insisten en ver el espacio marginal como un cuerpo cuya decadencia es síntoma de un momento de crisis social: "así el conventillo contrae su osamenta dentro de sus harapos" (Guzmán, 1995: 95) versus "las entrañas del barrio, sin afeites ni falsos ropajes"

las tetas generosas de doña Afrodita” (23). 14:30. En plan profesional "saqué mi auto de su estacionamiento y conduje hacia el Barrio Franklin" (31). 15:00. Entro en un garito, "Había una enorme barra en la que se acodaba media docena de hombres y diez mesas de pool ocupadas por jugadores de aspecto patibulario" (47). 18: 45. Regreso a casa mientras "Los bares y restaurantes del barrio comenzaban a llenarse de clientes. Desde sus interiores brota el eco bullicioso de las conversaciones animadas por la cerveza” (9). 
(Díaz, 2003: 15). Y, en cuarto lugar, Pablo y Heredia se dejan acariciar por el habla de la ciudad. La precariedad de los espacios les permite a ambos narradores escuchar bullas, murmullos y susurros que delatan los secretos de la intimidad: "como hermanos, zurcen la distancia con las agujas sonoras de sus cantos" (Guzmán, 1995: 41) versus "[en la noche] brotaba el eco melodioso de las conversaciones" (Díaz, 2003: 99) ${ }^{19}$.

\section{CONCLUSIÓN}

La enunciación de los hombres grises evoca la sentencia con la que Marx (1852) abre su estudio sobre la Comuna de París: "Hegel dice en alguna parte que todos los grandes hechos y personajes de la historia universal aparecen, como si dijéramos, dos veces. Sin embargo, se olvidó de agregar: una vez como tragedia y la otra como farsa" (405). Al igual que en los hechos de El 18 de brumario, en la enunciación de Díaz Eterovic u Oses asoman tanto una repetición como una farsa: por una parte, está la cita de los imaginarios urbanos inscriptos en la novela social pero, por otra, dicho gesto de recuperación del discurso frentepopulista vacía al pasado de todos sus bemoles. Ese resto que perpetuamente es desplazado de las hermenéuticas del recuerdo (Lizama, 2007: 17) asoma en un diálogo ejemplar de La patrulla. Allí, Pablo, un hijo de la autodenominada clase media, discute con un camarada sobre el proyecto educativo de Aguirre Cerda y sus epígonos:

-El Instituto Nacional nunca fue un colegio 'palta' [burgués], era un colegio fiscal, gratuito, pluriclasista, el mejor ejemplo del espíritu republicano y laico chileno. Tuve compañeros como el Pelado Lyon, que llegaba en Volvo a clases, o como el cojo Garrido, que vivía en una población

- ¿En cuál?

-No sé bien, por allá (82; las cursivas son mías).

El apresurado "No sé bien" marca una distancia insalvable entre el desinterés del hijo de la pequeña burguesía chilena (Juan Pablo) y el "por allá", ambigua marca que designa el espacio desconocido donde se atrinchera la

${ }^{19}$ El propio Díaz Eterovic ha explicitado que, para él, "La novela policial, en Chile y Latinoamérica, es la novela policial de nuestro tiempo, en tanto explora en las realidades más oscuras de nuestra sociedad (...). Considero que mis novelas beben de dos fuentes orientadas a la recreación de temas sociales y políticos: la novela negra que nació en los Estados Unidos a comienzos del siglo pasado, y la novela social que desarrolló en Chile la notable generación del 38 [42, según Goic]. Ambas expresiones son un referente importante en mi trabajo" (Díaz, 2008). 
alteridad obrera (el Cojo Garrido). Las palabras de Juan Pablo terminan por darle la razón a Lizama, quien considera que "lo que siempre queda fuera de estas 'hermenéuticas del recuerdo' es precisar que la ciudad de Santiago a la cual se alude es, específicamente, su exclusivo centro cívico" (17). Según Lizama, no se deben confundir las condiciones materiales y simbólicas en las que permanecen sumidos los obreros santiaguinos en las décadas de $1930-1950^{20}$ con las figuraciones urbanas que produjeron los novelistas de la generación de 1942: una ciudad cuyas "entrañas industriales" (Sepúlveda) "estiraban su osamenta crujiente” (Guzmán).

En marco de los debates culturales postdictatoriales, estos textos enseñan que la "amnesia" (suscitada por el neoliberalismo de los gobiernos de la Concertación), no es la única patología que amenaza la buena salud de nuestra memoria comunitaria; las recuperaciones historicistas ${ }^{21}$ del pasado asoman tan letales como el olvido.

La del hombre gris -concluyo entonces- es una enunciación sintomática de una actitud conservadora ante un inédito reacomodo social: los herederos de una clase media de abogados (El color de la piel), académicos universitarios (Machos tristes), comunicadores sociales (Mercenario ad-honorem, La secreta guerra santa), profesores y sociólogos (La patrulla), entienden la globalización como un proceso de homogeneización cultural cuya consecuencia inmediata es la pérdida de los privilegios de su propia clase. Esta merma simbólica los atemoriza mucho más que la orfandad social de los sectores proletarios y subproletarios, que sólo figuran como telón ornamental en estos escritos. Vistas así las cosas, en el cierre de este ensayo, me parece pertinente invocar la frase que pronuncia Seidler (2000) con ayuda de Benjamin: "Sólo mediante la voluntad de encarar el pasado con todas sus crueldades podemos aspirar a pensar con más claridad en el presente" (71).

\section{REFERENCIAS}

Aguirre Cerda, Pedro. 1939. Mensaje de S.E. el Presidente de la República en la apertura de las sesiones ordinarias del Congreso Nacional. Santiago: I. Fiscal.

${ }^{20}$ En 1972, el Ministerio de Vivienda y Urbanismo "había censado 275 campamentos (...). En ellos vivían 83.000 familias, las que reunían unas 456.000 personas. Es decir, que uno de cada seis habitantes del Gran Santiago, o el 16,3\% de la población urbana era poblador de un campamento" (De Ramón, 2000: 251).

${ }^{21}$ Recuérdese que, según Frederic Jameson (1999), historicistas son las reconstituciones del pasado que obliteran las ambivalencias y contradicciones de los procesos históricos (18-19). 
Avelar, Idelber. 2000. Alegorias de la derrota: la ficción post-dictatorial y el trabajo del duelo. Santiago: Cuarto Propio.

Cánovas, Rodrigo. 1997. Novela chilena: nuevas generaciones (el abordaje de los huérfanos). Santiago: Pontificia Universidad Católica de Chile.

Cohen, Gregory. 1991. Mercenario ad-honorem. Santiago: Editorial Arte Cien.

De la Parra, Marco Antonio. 1989. La secreta guerra santa de Santiago de Chile. Santiago: Planeta.

De Ramón, Armando. 2000. Santiago de Chile. Santiago: Sudamericana.

Díaz Eterovic, Ramón. 2003. El color de la piel. Santiago: Lom.

_. 2008. "En la pista de la fama: Díaz Eterovic", en Punto Final. Sep. 2007. [En línea] Disponible en http://www.puntofinal.cl/647/eterovic.htm [Consulta: 05/11/2008].

Goic, Cedomil. 1972. Historia de la novela hispanoamericana. Valparaíso: Universitarias.

Guzmán, Nicomedes. 1995 [1939]. Los hombres oscuros. Santiago: Zig-Zag, 3a ed. 1964 [1943]. La sangre y la esperanza. Santiago: Zig-Zag, 2a ed.

Jameson, Frederic. 1999 [1997]. Postmodernism, or, the cultural logic of late capitalism. Durkham: Duke UP.

Kristeva, Julia. 1995 [1989]. Black Sun. New York: Norton.

Lizama, Jaime. 2007. La ciudad fragmentada. Santiago: UDP.

Marx, Karl. 1852. El 18 de brumario de José Bonaparte. Marxist Internet Archive. Ed. J. Fajardo. [En línea] Disponible en http://www.marxists.org/espanol/me/1850s/brumaire/brum1.htm [Consulta: 20/07/2007].

Morand, Carlos. 1977. Visión de Santiago en la novela chilena. Santiago: Aconcagua.

Moulián, Tomás. 1997. Chile actual: anatomía de un mito. Santiago: LOM/Arcis.

Oses, Darío. 1991. Machos tristes. Santiago: Planeta.

Pavez, M. Isabel. 1996. "El Archivo Karl Brunner en F.A.U. de la Universidad de Chile-Antología", en Revista de Arquitectura 8, p. 38.

Rama, Ángel. 1984. La ciudad letrada. New Hampshire: Del Norte.

Seidler, Víctor. 2000. Masculinidades. Trad. J. Sarret. Madrid: Montesinos.

Sepúlveda Leyton, Carlos. Hijuna. 1962 [1934]. Santiago: Austral.

Spotorno, Radomiro. 1994. La patrulla de Stalingrado. Santiago: Planeta.

Subercaseaux, Bernardo. 2008. "Editoriales y círculos intelectuales en Chile 19301950," en Revista chilena de literatura 72, pp. 221-33.

Tromben, Carlos. 2003. Poderes fácticos. Santiago: El Mercurio/Aguilar. 